\title{
Activities - Enormous Importance in the Modern English Language Classroom
}

\author{
Bhargavi Pedda Ramireddy Gari, \\ Research Scholar, \\ English Department, \\ Sri Padmavathi Mahila Visva Vidyalayam, \\ Tirupati, India
}

\begin{abstract}
This paper aims to explore the importance and effectiveness of activities when they are used in EFL or ESL classrooms. And concentrating how activities are useful for the Primary and Secondary school students. These young learners are not in a matured time of their learning and cannot all find out the importance foreign language learning. But teachers and parents should make them understand and lead them towards language acquisition without fail. So, activities are the most discussable thing in joyful learning. Activities play a vital role in second language learning in terms of providing a stress free atmosphere for EFL learners in which there are fun, motivation, interest, curiosity to enhance their language learning.
\end{abstract}

Keywords:- Activities; Joyful learning; Primary and Secondary Students; EFL Classroom.

\section{INTRODUCTION}

Activities in a foreign language classroom provide a chance to develop basic language skills in an enjoyable manner. Activities are educationally valuable learning tool. According to Lee (1979)," games give a chance to escape from unusual routines, but they are very important in terms of motivation and challenges". Activities give encouragement to interact and communicate successfully with others. Activities persist the effort of learning and create a context to use the language meaningfully, decrease anxiety, and allow learners to study in a relaxed and enjoyable atmosphere.

This paper is going to discuss how activities help primary and secondary school students in learning English as a second language. According to Hadfield (1990), "a game is an activity with rules, a goal and an element of fun... Games should be regarded as an integral part of the language syllabus". This definition highly evaluates the importance of games in teaching. It shows that games serve not only as an 'amusing activity', but also as a technique to carry out many pedagogical tasks. The activities like conversation, dialogues, roleplay, compering, news reporting, announcements, debate create a chance for students to improve their speaking skill. According to Lee(1979), "games can be classified into ten categories: structure games which provide experience of the use of particular patterns of syntax in communication; vocabulary games in which the learners' attention is focused mainly on words; spelling, pronunciation games; number games; listen-and-do games; games and writing; miming and role play; discussion games".

\section{ROLE OF ACTIVITIES IN ENGLISH LANGUAGE TEACHING}

This 21st century shifted the play style of children compared to the rest of the centuries through Academic Organization's technology and working culture, especially schools. There are many studies that tell children to become more and more addicted to games because of the anxious academic structure to get comfortable. In this situation, while governments in primary and secondary school take great care of games in schools, the outcome is not likely to be a competitive atmosphere. So large numbers of parents in their home are building PlayStation for their children's health and demands. Activities will thus play a huge role in classroom language learning. Games and activities will motivate learners, promote interaction among learners and boost the acquisition of pupils. As a consequence, games can increase the achievement of learners, which ensures student test results, communication ability, vocabulary knowledge, or other language skills may boost.

Children can take advantage of the playtime. Activities offer a friendly, relaxed atmosphere in practice using the language skills and express themselves freely and improve their own abilities of learning. Participation of activities is an effective way to develop communication and language skills. Activities help make students feel socially comfortable and can be a means to build friendships.

Activities improve learners' achievement. Instead of traditional teacher centred methods, the unconventional teaching strategies like Activity based methods to be put into practice in the EFL classroom to grab the attention of the students which makes the students desire to learn and higher test scores.

Activities encourage learners' interaction. Interaction brings positive attitude, collaboration, team spirit among the students. Pair or group work is one of the most important ways to step up teamwork. Many activities can be played in pairs or in small groups, which create an opportunity to develop their negotiation skills such as the ability to 
respectfully disagree or the ability to ask for assistance. The learners will definitely be taking part in the activities in the classroom. Therefore, they are ready to share ideas in groups or in pairs, communicate and discuss topics with their peers, and think creatively about how to use foreign language to achieve their goals. The activities give students a great opportunity to work together and interact effectively with each other.

Activities improve learners' language acquisition ability of Students. They can obtain information quickly and more productively than other ways due to the inspiration and engagement provided by the games. Activities will inspire and motivate students to take part in the activity, because they obviously want to finish it. In addition to having fun, the learners are studying. The students try to use a new language and begin to understand that if they want others to hear what they're doing they must use the expression.

Games and activities can also lower anxiety. Students learn things faster and better in the easy, enjoyable atmosphere that is generated through the use of activities. The sense of the language students listening, reading, speaking and writing in will be understood more clearly in an activity. Activities are raising the accomplishment of the learners. Games and activities can include all of the basic language skills, i.e. listening, speaking, reading, and writing, and the same activity also involves a number of abilities.

In short, activities may be used as a useful learning tool for teaching English as a second language. They not only inspire learners but also create a friendly atmosphere in EFL classrooms. They aim to develop language skills. They can therefore inspire, encourage the engagement of the learners, enhance their learning and increase their achievement.

\section{TYPES OF ACTIVITIES}

As mentioned above, there are many practices in the language classroom that can promote learning and instruction in order to reach the learners ' targets as well as teaching in English as a second language classroom. They are:

- Individual activities

- Pair activities

- Group activities

The activities enable the students to be active class members, talk about themselves, resulting in long - term memory retention. The performance, interest, courage, enthusiasm, and freedom of expression. In order to fit all these items into a language learning classroom, activities are preferred and useful to include second language learning.

Here are some samples of Activities that combine language teaching and learning with fun:

\section{A. Word activities:}

Expand word play using the children's language. Activities can be used to enhance students' active and passive vocabulary. Find your partner, fill in the gaps, spin wheel, matching pictures with words, word ladder etc activities promote the development of vocabulary and communication skills.

\section{B. Translation activities:}

Translation activities involving bilingual translation between English and the students' mother tongue. Students feel completely at home as long as they have the mother tongue to fall back on while having to communicate in the class. Mother tongue supports to promote the target language to learn a language and get mastery over the target language. Mother tongue gives confidence to them by recollecting their previous linguistic experiences. Paragraph writing, Notice writing, Poster making, Invitation card Script for speech, Slogans, Messages, all these translation activities enhance the linguistic knowledge of the second language

\section{Jokes and Riddles:}

Jokes and Riddles are fun ways of using vocabulary and of drawing pictures of scenes or scenarios. Telling jokes or asking riddles aloud to each other and explaining them creates a lot of opportunities to learn language.

\section{Rhymes:}

The repeated singing, reading, writing or listening to rhymes, apart from learning voice, encourages good listening skills and memory retention. You can also use rhyming words to narrate what you do at school, or let your students tell you their favourite things using rhyming words.

\section{E. Storytelling:}

Although storybooks offer enough fun. Stories give students a good time to connect although helping them develop their communication skills. Exchange tales of everyday happenings. Broaden students' minds with fantastic stories and inspire their ingenuity to thrive as they create stories about everything and anything around them.

\section{F. Songs:}

Songs even help students learn new vocabulary. Lyrics have a sense of rhythm and melody and their singing along will be simple and enjoyable. On top of that, simply playing a melody on an activity can be fun to students.

\section{G. Tongue twisters:}

Tongue twisters are a great and enjoyable way to teach children to pronounce and enunciate words correctly. It's a nice way to teach utter words in an appropriate way. We can begin this activity with simple ones, and then complex one.

\section{H. Conversations, Skits, Roleplays:}

These activities can be used to improve fluency and give confidence and also increase their public speaking ability.They promote collaboration among students. These activities create context in which the language is useful and 
meaningful. The students get a positive attitude towards language learning.

\section{BENEFITS OF ACTIVITIES IN LANGUAGE LEARNING.}

Let 's explain that we should be using activities to teach vocabulary. Activities are a welcome break from the daily traditional class routine; learning a language calls for a lot of effort. Activities help students allow and support learning efforts and ignites the initial sparks to motivate students and provoke discussion and also stretches the students 'productive abilities in basic language skills, i.e. listening, speaking, reading and writing, and many abilities are often used in the same activity; Activities can be a very valuable element of the teaching. A good activity is specifically relevant to the content, it is suitable for all class members, and therefore the learners ' enjoyment is increased through it.

Activities give motivation and the students get involved in their learning process and spontaneous use of language is encouraged then promote four basic language skills. A lot of fun can be created by the activities. The activities based on stories, songs make students more enthusiastic. Taking these factors into consideration, teachers may be encouraged to use activities in the classroom to help learn vocabulary. Indeed, activities can instruct, and they bring genuine pleasure in learning a language.

\section{ROLE OF TEACHER WHILE DOING ACTIVITIES}

Teacher's role may not seem very much there, but a lot of work is done behind the activities. Teacher acts as an Instructor and a facilitator. Start inspiring students to participate well by building an enjoyable learning environment where they can enhance their imagination and develop their language skills. Teacher give proper guidance to them on how to properly convey their thoughts, feelings and ideas by using words as this leads to improving their communication skills.

Activities help the teachers build situations where the vocabulary is meaningful and useful. Even though activities are often synonymous with fun, teachers should be aware of the pedagogical value, especially in teaching the foreign language. Teachers are effective as they develop confidence, lower the pressure of the students and offer the chance for real contact to language learners.

Teachers help the students by creating contexts through the activities to make language learning useful and meaningful. The students want to take part in the activities in order to understand what others are saying or have written, and they must speak or write in order to express their own ideas to share with others with the help of the teacher.

\section{CONCLUSION}

As this paper till now discussed on second language acquitting learning through activities, they encourage creative and spontaneous use of language. They also promote communicative competence, fun. and reinforce language learning. They both support and extend learning in a communicative manner. Activities are extremely student centred; the teacher acts only as facilitator. They develop class cohesion, they can foster whole class participation, and promote healthy competition among students. Activities are used to overcome language learning hurdles and make the students free from the usual routine of the conservative teaching method. Students are motivated and take Learning as a challenge. Activities help students to make and sustain the effort of learning. They provide practice in the basic language skills - listening, speaking, reading and writing. They encourage students to interact and communicate. They instil characteristics like sharing, respecting, collaborating and cooperating with others among students and create a meaningful context for language learning.

\section{REFERENCES}

[1]. Carrier, M., \& Centre for British Teachers. (1985). Take 5. Games and activities for the language learners. (2d. ed.). London: Nelson and Sons Ltd.

[2]. Clément, R., Gardner, R. C. \& Smythe, P. C. (1980). Social and Individual Factors in Second Language Acquisition. Canadian Journal of Behavioural Science, 12(4), 293-302.

[3]. Hadfield,J. (1990). Intermediate Communication Games. England: Longman.

[4]. Lee,W.R.(1979). Language Teaching Games and Contests. (2d. ed.). Oxford:Oxford University Press.

[5]. Zahorik, J. A. (1996) Elementary and Secondary Teachers' Reports of How They Make Learning Interesting. The Elementary School Journal, 96, 551564.

[6]. Zourou, K. (2012). On the attractiveness of social media for language learning: A look at the state of the art. ALSIC, 15(1).) Retrieved: http://alsic.revues.org/2436

[7]. Rinvolucri, M. 1993. 'Teacher role play to attack prejudice' in Modern English Teacher vol 2/4 pp. 38 9.

[8]. Woodward, T. 2001. Planning Lessons and Courses. Cambridge University Press.

[9]. https://www.britishcouncil.my/english/courseschildren/resources/fun-activities-that-developlanguagelearning\#: :text=Participating\%20in\%20recre ational\%20activities\%20is, Word\%20games.

[10]. http://interconf.fl.kpi.ua/node/1271 